\title{
АНАЛІЗ ІНСТРУМЕНТІВ МАРКЕТИНГОВОЇ КОМУНІКАЦЙНОЇ ПОЛІТИКИ ПІДПРИЄМСТВА В СИСТЕМІ МЕНЕДЖМЕНТУ ОРГАНІЗАЦІї
}

\author{
Чупир О.М., о.е.н., доцент, професор, \\ Сичова О.С., к.е.н., доцент, доцент (ХНУБА)
}

Стаття присвячена аналізу основних сучасних інструментів маркетингової комунікаційної політики підприємства, формуванню конкретного комплексу засобів маркетингових комунікачій $i$ визначенню оптимальної системи контролю якості маркетингової комунікаційної політики компанії иляхом аналізу існуючих інструментів $і$ методів комунікаиійної політики. Авторами досліджено роботи відомих науковців стосовно контролю якості прочесів, запропоновано морфологічний аналіз поняття «маркетингова комунікаційна політика».

Ключові слова: інструменти маркетингової комунікаційної політики, контроль якості, інформаційно-аналітична діяльність.

\section{АНАЛИЗ ИНСТРУМЕНТОВ МАРКЕТИНГОВОЙ КОММУНИКАЦИОННОЙ ПОЛИТИКИ ПРЕДПРИЯТИЯ В СИСТЕМЕ МЕНЕДЖМЕНТА ОРГАНИЗАЦИИ}

\author{
Чупьрь Е.Н., д.э.н., доцент , профессор, \\ Сычёва Е.Е., к.э.н, доцент, доцент (ХНУСА)
}

\begin{abstract}
Статья посвящена анализу основных современных инструментов маркетинговой коммуникаџионной политики предприятия, форммированию конкретного комплекса средств маркетинговых коммуникаций и определению оптимальной системы контроля качества маркетинговой коммуникационной политики компании путем анализа существующих инструментов и методов коммуникачионной политики. Авторами исследованы работы известных ученьх в отношении контроля качества прочессов, предложен морфологический анализ понятия «маркетинговая коммуникационная политика».
\end{abstract}

Ключевые слова: инструменты маркетинговой коммуникационной политики, контроль качества, информационно-аналитическая деятельность.

\section{ANALYSIS OF MARKETING TOOLS OF COMMUNICATION POLYCY OF THE ENTERPRISE IN THE MANAGEMENT SYSTEM OF THE ORGANIZATION}

Chupyr O.N., doctor of economic sciences, associate professor, professor, Sychova O.E., candidate of economic sciences, associate professor (KNUBA)

The article is sanctified to the analysis of basic modern instruments of marketing of communication politics of enterprise, forming of concrete complex of facilities of marketing communications and determination of the optimal checking of quality of marketing of

(с) Чупир O.М.,

Сичова О.С.
Вісник економіки транспорту і промисловості № 57, 2017 
communication politics of company system by the analysis of existent instruments and methods of communication politics. Works of the known scientists are investigational authors in relation to control of quality of processes, the morphological analysis of concept "marketing of communication politics" is offered. For successful activity on the market, the company must have an effective strategy for the operation, including the marketing elements in the management of the organization. Marketing communication policy is an important part of enterprise management system, so the authors proposed a morphological analysis of this concept.

Keywords: instruments of marketing of communication politics, control of quality, research and information activity.

Постановка проблеми. Успішна діяльність будь-якого підприємства повинна забезпечуватися необхідними потоками інформації, які формують так звану систему комунікацій. Якщо внутрішні комунікації здійснюються всередині підприємств, то зовнішні комунікації здійснюються між підприємствами і окремими людьми, групами, сегментами суспільства, 3 якими воно взаємодіє. Багато науковців зазначають, що як стратегія маркетингу, так і стратегії менеджменту (мова йде про усі різновиди менеджменту, наприклад, стратегічний, інноваційний, інвестиційний, антікризизовий, фінансовий та інші) не може бути реалізована без наявності на підприємстві власної комунікаційної системи [8]. Тому необхідно провести аналіз поняття політики маркетингових комунікацій, розглянути основні інструменти та систему контролю якості реалізації комунікаційної політики.

Аналіз останніх досліджень i публікацій. Тема методології маркетингової комунікаційної політики та контроля якості комунікацій у наш час набуває особливої актуальності. Питанням комунікаційної політики присвятили свої праці як вітчизняні, так і зарубіжні вчені: А. Войчак, О. Братко [4], Д. Аакер [9], Ф. Котлер [2], П. Сміт, К. Беррі, А. Пулфорд [5], Дж. Бернет, С. Моріарті [6] та інші. В їх роботах висвітлено підходи до втілення окремих засобів маркетингових комунікацій але питання аналізу інструментів комунікаційної політики залишається відкритим і потребує подальшого дослідження в системі менеджменту організації.

Виділення невирішених частин загальної проблеми. Кожна компанія у своїй діяльності повинна взаємодіяти 3 маркетинговим середовищем, невід'ємною частиною якого є споживачі продуктів чи послуг. 3 метою ефективної взаємодії 3 клієнтами компанія повинна застосовувати різні інструменти комунікаційної політики. Своєчасним й актуальним є питання щодо використання засобів маркетингових комунікацій і механізмів контролю якості комплексів маркетингових комунікацій (далі КМК), часто підприємства й організації ведуть обмін інформацією 3 зовнішнім середовищем без чітких механізмів і плану, що може негативно вплинути на майбутнє компанії. Враховуючи наведені доводи, основними завданнями статті є: дослідження основних теоретико-методологічних аспектів маркетингової комунікаційної політики; виділення основних сучасних інструментів KMK.

Метою статті є формування механізму для контролю якості реалізації маркетингових комунікацій.

Виклад основного матеріалу дослідження. Для успішної діяльності на ринку підприємству необхідно мати ефективну стратегію функціонування 3 урахуванням елементів маркетингу при здійсненні управління організацією. Маркетингова комунікаційна політика $€$ важливою частиною системи управління підприємством, тому авторами запропоновано морфологічний аналіз цього поняття (рис. 1). 


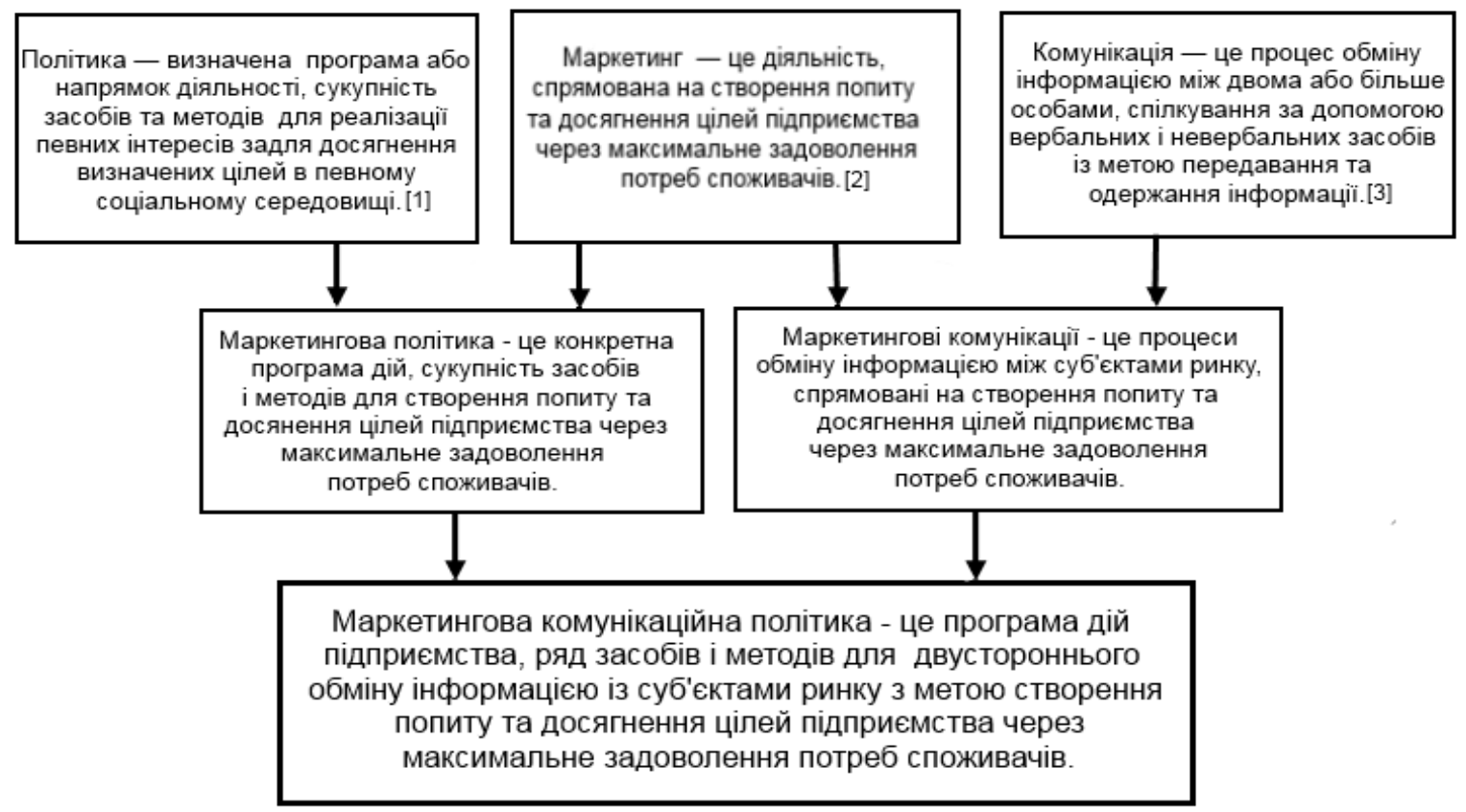

Рис. 1. Морфологічний аналіз поняття «маркетингова комунікаційна політика» [Авторська розробка]

Аналізуючи роботи П. Сміта, К. Беррі, А. Пулфорда [5], Дж. Бернета та С. Моріарті [6] авторами було визначено основні завдання сучасної маркетингової комунікаційної політики :

- планування,

організація, впровадження й оцінювання комунікацій;

- сегментація та цільова взаємодія 3 пріоритетними аудиторіям;

- використання ефективних каналів для комунікацій компанії;

- інформування, збір інформації та формування стабільної репутації компанії й управління репутаційними ризиками;
- розробка стратегій i тактичних рішень для кризових комунікацій;

- взасмодія зі ЗМI на національному та регіональному рівні;

- позиціонування керівництва та

публічних персон компанії в інформаційному полі.

Процес комунікації можна розглядати за допомогою різних комунікаційних моделей. Найбільш простою $є$ модель ДПКО (Джерело Повідомлення - Канал - Одержувач). На рис. 2 зображена комунікаційна модель й основні їі елементи.

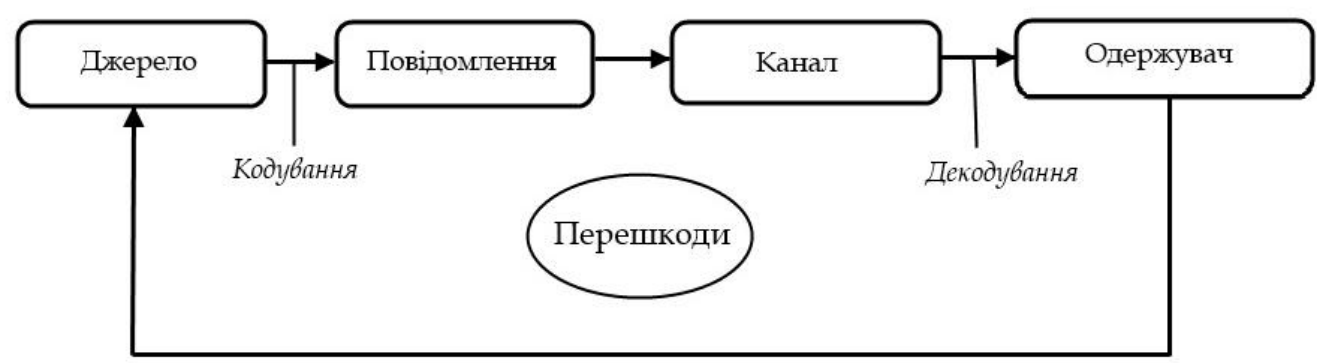

Зворотніиі з 'язок

Рис. 2. Комунікащійна модель 
У моделі процесу комунікацій виділяють такі елементи: відправник (окрема особа або організація) - джерело повідомлення; кодування - процес перетворення ідей на символи, зображення, малюнки, форми, звуки, мову й т. п.; звернення - сукупність символів, що передаються відправником. Більшість звертань передається у вербальній, тобто словесній формі. Однак звертання може бути і невербальним (жести, міміка або графічне зображення); засоби поширення інформації — канали передачі, по яких сигнал передається від відправника до одержувача. До засобів масової інформації належать технічні засоби поширення інформації (друк, радіо, телебачення); розшифровка - процес, за допомогою якого одержувач приписує значення символам, що надійшли від відправника; одержувач - цільова аудиторія; реакція у відповідь - сукупність відгуків одержувача для ознайомлення зі звертанням, яка призводить до зміни в поведінці одержувача. Поняття ефективної комунікації 3 точки зору відправника передбачає отримання інформації одержувачем і реакцію у відповідь згідно 3 прогнозом відправника.

Модель дозволяє також виявити ключові умови ефективної комунікації. Відзначимо серед них такі: 1) цілі комунікації; 2) підготовка звернення; 3) планування каналів; 4) ефективність звернення. Основні етапи роботи над створенням діючої системи комунікацій: виявлення цільової аудиторії; визначення ступеня купівельної готовності аудиторії; визначення бажаної відповідної реакції цільової аудиторії; складання звертання до цільової аудиторії; формування комплексу маркетингових комунікацій фірми; розробка бюджету комплексу маркетингових комунікацій; перетворення в життя комплексу маркетингових комунікацій; збирання інформації, що надходить по каналах зворотнього зв'язку; коректування комплексу маркетингових комунікацій [4].
На думку авторів П. Сміта, К. Беррі й А. Пулфорда в комунікаційний набір, крім традиційних інструментів, входять наступні: упакування, продавці, компанії просування на місцях продажів i стимулювання торгівлі, неформальне судження, корпоративний імідж [5]. Схожої точки зору дотримуються Дж. Бернет і С. Моріарті, що доповнюють “класичний" склад із п'яти елементів наступними комунікаційними інструментами: спеціальні засоби для стимулювання торгівлі чи рекламно-інформаційні засоби; упакування; спеціальні сувеніри; спонсорство; надання ліцензії та сервісне обслуговування [6]. Таким чином, 3 урахування сучасного рівня розвитку техніки та технології авторами було виділено наступні комунікаційні інструменти, як:

• упакування, компанії просування на місцях продажів i стимулювання торгівлі (спеціальні засоби для стимулювання торгівлі чи рекламноінформаційні засоби), як правило, мають значення, що вирішує, для просування на ринок товарів широкого споживання:

- $\quad$ спеціальні сувеніри чи акції $\epsilon$ одним із засобів стимулювання збуту;

- спонсорство, неформальне судження, корпоративний імідж входять в основний інструмент КМК - паблік рілейшнз;

$\begin{array}{ccc}\bullet & \text { iнтернет i нові середовища } \\ \text { відносяться } & \text { до елементів прямого } \\ \text { маркетингу; } & & \end{array}$

- $\quad$ продавці (фахівці по роботі зі споживачами) та сервісне обслуговування стосовно до телекомунікаційної сфери варто відносити до персональних продажів.

Важливим питанням $\epsilon$ аспект контролю якості реалізації маркетингової комунікаційної політики. Авторами було досліджено роботи відомих науковців стосовно контролю якості процесів. Американський вчений, статист Едвард Демінг творчо розвинув і обгрунтував ідеї методів контролю й управління якістю, i 
вперше розробив програму, спрямовану на підвищення якості праці. Демінг стверджував, що будь-яка діяльність може розглядатися як технологічний процес i тому може бути поліпшена.

Демінг розробив досить лаконічний цикл у вигляді системи контролю та поліпшення якості продукту, послуги, процесу та будь-якої діяльності (рис. 3). Таким чином, ми бачимо, що на початковому етапі планується процес маркетингової комунікаційної політики, встановлюються цілі, засоби, нормативи, визначають строки, відповідальних й обирають інструменти КМК.

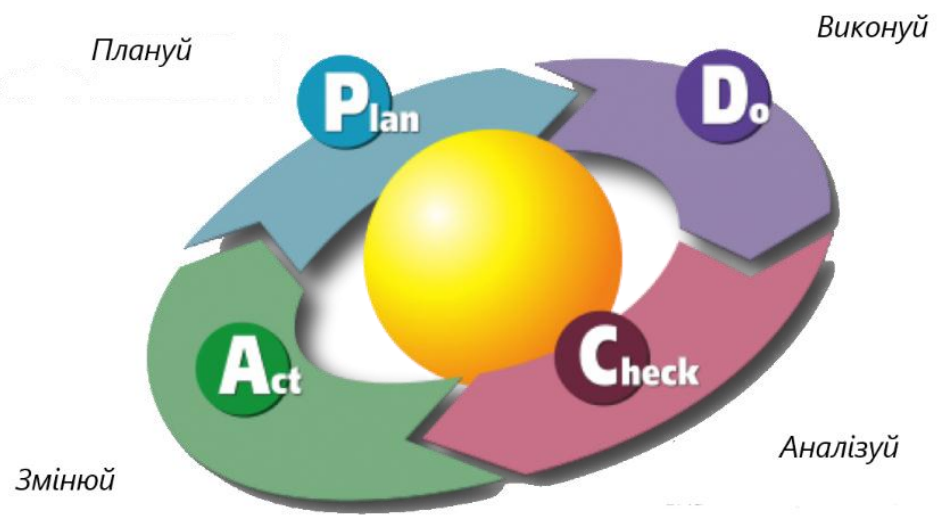

Рис. 3. Цикл контролю якості Демінга [7]

Після чого плани реалізують. Потім йде збір і аналіз результатів діяльності, визначають відхилення та причини невідповідностей. На наступному етапі усувають недоліки і знову планують. Цикл Демінга досить чітко відображає процес контролю якості комунікаційної політики.

Висновки даного дослідження i перспективи подальших робіт у цьому напрямку. Під комунікаційною системою слід розуміти систему заходів творчої й операційної діяльності, що об'єднує учасників, канали, носії, форми, методи та технології комунікацій, і яка створена для реалізації збутових й інших задач підприємств, громадських організацій, індивідуальних осіб і держави в цілому шляхом інформаційного впливу на споживачів. У наш час компанії діють у досить динамічному просторі й необхідним фактором є обмін інформацією із зовнішнім середовищем. Вирішенням цього питання $\epsilon$ розумна маркетингова комунікаційна політика. У ході написання статі було проаналізовано основні теоретичні аспекти маркетингової комунікаційної політки, розглянуто сучасні інструменти комунікацій, запропоновано механізм для контроля якості реалізації комплексу маркетингових комунікацій. Зовнішне середовище постійно змінюється й тому вивчення тематики підлягає подальшому дослідженню, наприклад, в області оцінки ефективності інструментів маркетингових комунікацій.

\section{ПЕРЕЛІК ВИКОРИСТАНИХ ДЖЕРЕЛ}

1.Росситер Дж., Реклама и продвижение товаров / Дж.Росситер, Л.Перси. СПб.: Питер, 2001. - 656 с., С 89.

2. Котлер Ф. Маркетинг. Туризм./ Ф.Котлер, Дж.Боуэн, Дж.Мейкенз. К: КДЕУ, 2000. — 75-79 с.

3.Гаркавенко С. С. Маркетинг. / Гаркавенко С. С. - Київ: Лібра, 2002. - 712 c., C.-14. 
4.Павленко А. Ф. П 12 Маркетинг. / А. Ф.Павленко, А. В. Войчак- К.: КНЕУ, 2003. - 246 c.,

5.Сміт П. Коммуникації стратегічного маркетингу / П.Сміт, К.Беррі, А. Пулфорд- М.: Юніті-Дана, 2001. - 212 с., C 76.

6.Бернет Дж. Маркетингові комунікації / Дж Бернет., С. Моріарті. СПб: Пітер, 2001. - 124 с., С 34.

7.Деминг Є. Выход из кризиса. Новая парадигма управления людьми, системами и процессами / С. Деминг- М.: $738 \mathrm{c}$. «Альпина Паблишер», 2011. -101 с.
8.Бебик B.M. Інформаційно комунікаційний менеджмент у глобальному суспільстві: психологія, технологія, техніка паблік рилейшнз: Монографія. / В.М. Бебик. - К.:МАУП, 2005. - 483 с.

9.Дэвид А. Аакер .Стратегическое рыночное управление. Бизнес-стратегии для успешного менеджмента. / А.Дэвид Издательство: Питер, 2003- 234с

10.Уильям Уэллс Реклама. Принципы и практика / Уильям Уэллс, Сандра Мориарти. -М.: Букинист, 2008. -

\title{
УДК 65.012.32:656.2
}

\section{МЕТОДИКА СТРАТЕГІЧНОГО УПРАВЛІННЯ У ТЕРИТОРІАЛЬНО- ГОСПОДАРСЬКИХ ПІДСИСТЕМАХ}

\author{
Янченко Н.В., к.е.н., доцент (ХНУБА)
}

В статті відображена актуальність удосконалення стратегічного управління у територіально-господарських підсистемах в умовах трансформаційної економіки, виділені проблемні питання та економічні переваги від досягнення оптимального співвідношення між керуємою і керуючою підсистемами. Розроблено методику реалізаиіі комплексної оцінки соціально-економічної ефективності управлінських рішень у територіально-господарських підсистемах.

Ключеві слова: територіально-господарська підсистема, соціально-економічна ефективність, регіональне управління, управлінські рішення, оцінка, стратегія управління.

\section{МЕТОДИКА СТРАТЕГИЧЕСКОГО УПРАВЛЕНИЯ В ТЕРРИТОРИАЛЬНО-ХОЗЯЙСТВЕННЫХ ПОДСИСТЕМАХ}

\author{
Янченко Н.В., к.э.н, доцент (ХНУСА)
}

\begin{abstract}
В статье отображена актуальность усовершенствования стратегического управления территориально-хозяйственными подсистемами в условиях трансформачионной экономике, выделены проблемные вопросы и экономические преимущества от достижения оптимального соотношения между управляемой и управляющей подсистемами. Разработана методика реализации комплексной оценки сочиильно-экономической эффективности управленческих решений в территориальнохозяйственных подсистемах.
\end{abstract}

(C) Янченко Н.В.

Вісник економіки транспорту і промисловості № 57, 2017 